\title{
Comparative account of water chemistry of three perennial rivers of Morang district, Province No. 1, Nepal
}

\author{
B.R. Subba ${ }^{1^{*}}$, N. Balmiki ${ }^{2}$ and P.K. Yadav ${ }^{1}$ \\ ${ }^{1}$ Department of Zoology, Post Graduate Campus, T.U., Biratnagar, Nepal \\ ${ }^{2}$ Central Department of Environmental Science, Kirtipur, T.U., Nepal \\ *E-mail: subbabharatraj@gmail.com
}

\begin{abstract}
A comparative study of water chemistry of Keshaliya, Shinghiya and Lohandra rivers of Province No 1, Morang District, Nepal was performed for one spring season in 2016. Altogether 18 physicochemical parameters were selected to be determined for each river during spring season. The values of each parameter recorded for the above rivers were $\mathrm{pH}(6.59$ to 8.08$)$, temperature $\left(22.4\right.$ to $\left.30.3^{\circ} \mathrm{C}\right)$, electrical conductivity (336 to $537 \mathrm{NTU})$, DO (4.17 to $10.65 \mathrm{mg} / \mathrm{l})$, total dissolved solids (168 to $268.5 \mathrm{mg} / \mathrm{l})$, total hardness (145 to $204 \mathrm{mg} / \mathrm{l})$, calcium hardness (106 to $180 \mathrm{mg} / \mathrm{l})$, total alkalinity (172 to $226 \mathrm{mg} / \mathrm{l})$, Silica (180 to $393 \mathrm{mg} / \mathrm{l})$, total nitrogen $(4.2$ to $14 \mathrm{mg} / \mathrm{l})$ total phosphorous $(0.07$ to $0.45 \mathrm{mg} / \mathrm{l})$, BOD (4.24 to $126.27 \mathrm{mg} / \mathrm{l})$, COD $(9.20$ to $252 \mathrm{mg} / \mathrm{l})$, nitrate $(<0.05$ to $0.18 \mathrm{mg} / \mathrm{l})$, chloride (4 to $36 \mathrm{mg} / \mathrm{l}$ ), magnesium (4.13 to $21.4 \mathrm{mg} / \mathrm{l}$ ) and calcium $(12.15$ to $72.29 \mathrm{mg} / \mathrm{l})$.
\end{abstract}

Key words: Spring season, water quality, Dissolve Oxygen, Alkalinity

\section{Introduction}

Water is one of the most important components required in sustaining life for all living organisms. Mostly for aquatic life, water is considered as a major thing to be alive. As condition of aquatic life directly reflects the properties of water and vice versa; the knowledge of water chemistry is paramount important for understanding aquatic life processes of all aquatic organisms including fishes. Considering importance of water quality, any works related to either of lotic or lentic water, first attempt is always made for testing of water properties following standard methods throughout the world. Rivers of Morang district were almost safe till three decades back but within three decades drastic changes have appeared in the rivers. Bulging out rural population and industrial areas has taken place because mainly of public migration, industrialization, urbanization, increasing construction works every day, increasing number of vehicles and their related workshops seem to have been creating problems year after year in the city and settlement areas. Tons of garbage, effluents and sewage are produced every day. The most popular place for dumping of the waste products has been the rivers. Most of the poor public either of urban or rural areas are not in position to have their own latrines or public conveniences so they are bound to go to riversides for excreting. These sort of public activities also add pollution load to the rivers.

The present study has attempted to study of some of the important parameters pertaining to water chemistry of three major rivers of Morang district in spring season.

\section{Study sites}

Morang district is considered as one of the historical industrial districts of the country situated in the Tarai region of Province No 1. It is rich in water resources. The three perennial rivers Keshaliya (N 26027'02.4" - E 087014'43.3"), Singhiya (N 26026'15.3"-E 
$087^{0} 18^{\prime} 00.1^{\prime \prime}$ ) and Lohandra (N 26027'31.7"-E 087 20'02.0") (Fig. 1) flow southwards penetrating Morang district, after originating from Churia hills (Siwalik hills). These are the main rivers for capture fisheries in the district. With increase in industrialization, urbanization and constructional works, day by day, the aquatic life of these rivers have been suffering from increasing pollution load. Industrial effluents, domestic sewage, disposal of garbage, human excreta, washed out or leached fertilizers and pesticides from agricultural fields etc. constitute main bulk of pollutants in the river. The objective of the present work was to make a comparative account of the properties of freshwaters of the three major rivers of Morang district mentioned above.

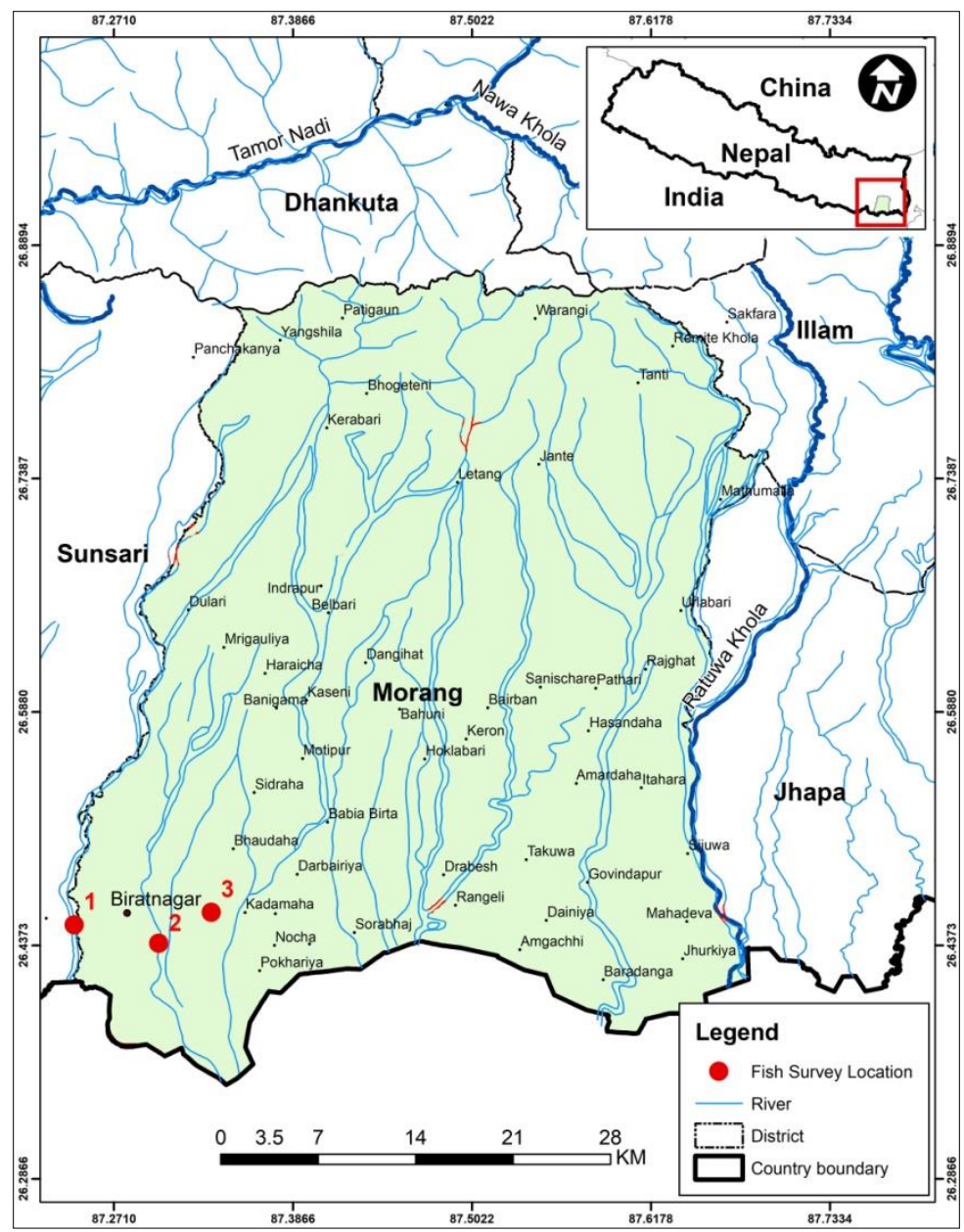

Figure 1. Map of the study area

\section{Materials and Methods}

Water samples were collected in standard polythene bottles from 8 am to 9 am from fixed spots of the rivers, every month and transported to the Laboratory of Nepal Environmental Service Centre, Biratnagar, Nepal within one hour. The water samples were subjected to analysis using different standard methods prescribed by APHA (1998) in Nepal Environmental Service Centre, Biratnagar Nepal. 


\section{Results and Discussion \\ Temperature}

Ambient temperature of the three rivers Keshaliya, Singhiya and Lohandra in the month of March was almost same $\left(22.5^{\circ} \mathrm{C}, 22.5^{\circ} \mathrm{C}\right.$ and $22.4^{\circ} \mathrm{C}$, respectively). In April, the temperature raised by 1.9, 1.6 and 2 in Keshaliya, Singhiya and Lohandra, respectively from that of March. As the month proceeded towards summer season, the temperature recorded in May was $30^{\circ} \mathrm{C}, 20.2^{0}$ and $30.3^{\circ}$ for Keshaliya, Singhiya and Lohandra, respectively.

\section{Electrical conductivity}

523 NTU, 455 NTU and 537 NTU were the electrical conductivity recorded in March, April and May, respectively in Keshaliya. The recorded values of electrical conductivity in the same months in Singhiya were 452 NTU, 435 NTU and 433 NTU whereas the values were markedly different, 387 NTU, 336 NTU, 338 NTU in March, April and May, respectively in Lohandra. It suggested that Lohandra river is less polluted than the Keshliya and Singhiya being within industrial Biratnagar metropolis.

It was 22.77, 12.29 and 81 NTU in March; 44, 28.83 and 52 NTU in April, 24.11, 30.64 and 70 NTU in May, in case of Keshaliya, Singhiya and Lohandra rivers respectively. To be the turbidity higher in case of Keshaliya in March and May but it was higher in April in Singhiya April. These sorts of results attributed to greater humnan interference and sand miming, from the rivers on the respective rivers in the months mentioned. However, water of the experiment rivers are total dissolved solids intermodiate one. It was $261.5 \mathrm{mg} / \mathrm{l}$, $227.5 \mathrm{mg} / \mathrm{l}$ and $268.5 \mathrm{mg} / \mathrm{l}$ in March, April and May respectively in the case of Keshaliya.

The values $226 \mathrm{mg} / \mathrm{l}, 217.5 \mathrm{mg} / \mathrm{l}$ and $216.5 \mathrm{mg} / \mathrm{l}$ for total solid dissolved were recorded in March, April and May respectively in Singhiya. Similarly, in the months of March, April and May, the estimation of total dissolved solids resulted $193.5 \mathrm{mg} / \mathrm{l}, 168 \mathrm{mg} / \mathrm{l}$ and 169 $\mathrm{mg} / \mathrm{l}$ in Lohandra. To be comparatively higher, the estimated values of total dissolved in all months in case the case of Keshaliya and Singhiya might attribute to pollution. These rivers do receive several tons of sewage, industrial effluents from the industrial metropolis.

Total Hardness as $\left(\mathrm{CaCO}_{3}\right)$

Hardness of water is caused mainly due to the presence of calcium and magnesium salts and in addition to these there are several organic and inorganic chemicals which alter the softness of water to hardness through chemical processes. The estimated values of the total hardness as $\left(\mathrm{CaCO}_{3}\right)$ in the waters of rivers Keshaliya (K), Singhiya (S) and Lohandra (L), in the months of March (M), April (A) and May (M) were $199 \mathrm{mg} / \mathrm{l}, 99 \mathrm{mg} / \mathrm{l}$ and $179 \mathrm{mg} / \mathrm{l}$; $204 \mathrm{mg} / \mathrm{l}, 197 \mathrm{mg} / \mathrm{l}$ and $107.33 \mathrm{mg} / \mathrm{l}$ and $170 \mathrm{mg} / \mathrm{l}, 167 \mathrm{mg} / \mathrm{l}$ and $145 \mathrm{mg} / \mathrm{l}$, respectively. The calcium hardness estimated in these three rivers in the month of March was 160.71 $\mathrm{mg} / \mathrm{l}, 157.37 \mathrm{mg} / \mathrm{l}$ and $132.91 \mathrm{mg} / \mathrm{l}$, respectively. Similarly the values for calcium hardness of water estimated $180.73 \mathrm{mg} / \mathrm{l}, 155.15 \mathrm{mg} / \mathrm{l}$ and $166.27 \mathrm{mg} / \mathrm{l}$ were in April, $152.92 \mathrm{mg} / \mathrm{l}$, $107.33 \mathrm{mg} / \mathrm{l}$ and $106.21 \mathrm{mg} / \mathrm{l}$ in May. The values were found to be close to the permissible limit however, hardness of $\mathrm{K}$ and S rivers indicated more than that of $\mathrm{L}$. It is because of the former rivers receive more pollutants from industrial metropolis Biratnagar than L river which flows far away from the industrial area. 


\section{Total Alkalinity as $\left(\mathrm{CaCO}_{3}\right)$}

The total alkalinity recorded in these rivers were $204 \mathrm{mg} / \mathrm{l}, 212 \mathrm{mg} / \mathrm{l}$ and $216 \mathrm{mg} / \mathrm{l}$ in March; $212 \mathrm{mg} / 1,202 \mathrm{mg} / \mathrm{l}$ and $226 \mathrm{mg} / \mathrm{l}$ in April and $180 \mathrm{mg} / 1$ 172 mg/l, 176 mg/l in May respectively. The values of total alkalinity estimated in Keshaliya were lower than those of Singhiya and Lohandra. This result indicated that Keshaliya river is more loaded with pollutants of metropolis Biratnagar than the later ones.

\section{pH}

$\mathrm{pH}$ values of both totic and lentic water resources determine the water quality and that of productivity nature, and organic life style living condition. The $\mathrm{pH}$ values recorded in Keshaliya, Singhiya and Lohandra rivers were 6.59, 7.36 and 6.8; 6.95, 7.26 and 7.1, and 7.14, 8.08 and 7.5, respectively for the months of March, April and May. pH value of Keshaliya seemed to be more acidic in nature than alkali as $\mathrm{pH}$ recorded in March and May were 6.59 and 6.8, respectively (table 1). It also showed that water of Keshaliya river is more polluted by industrial effluents and domestic wastes of metropolis Biratnagar. However, the range of $\mathrm{pH}$ is optimum for most of the aquatic organisms.

\section{Total Nitrogen}

It is one of the important plant nutrients, which indicates how productive is the aquatic systems. In lotic aquatic systems, its presence indicates variable condition. The recorded values of total nitrogen in the month of March, April and May were 7mg/1, $4.2 \mathrm{mg} / \mathrm{l}$ and $5,60 \mathrm{mg} / \mathrm{l}$ for Keshaliya river; $4.2 \mathrm{mg} / 1,5.60 \mathrm{mg} / 1$ and $4.60 \mathrm{mg} / \mathrm{l}$ were for Singhiya river in the month of April, similarly for Lohandra river in the month of May, the estimated values were $4.20 \mathrm{mg} / \mathrm{l}, 14 \mathrm{mg} / \mathrm{l}$ and $11.2 \mathrm{mg} / \mathrm{l}$ (Table 1). The results showed that Lohandra river is more productive than Keshaliya and Singhiya rivers. This was supported by the observations made during fish collection time.

\section{Phosphate-Phosphorus}

Excess amount of phosphate-phosphorus, in any aquatic system results eutrophication, it being major source of water pollution. It also acts as a limiting factor being an important plant nutrient. Variation in results was observed in different rivers and months. It was 0.21 $\mathrm{mg} / \mathrm{l}, 0.45 \mathrm{mg} / \mathrm{l}$ and $0.33 \mathrm{mg} / \mathrm{l} ; 0.07 \mathrm{mg} / \mathrm{l}, 0.27 \mathrm{mg} / \mathrm{l}$ and $0.23 \mathrm{mg} / \mathrm{l}$, and $0.18 \mathrm{mg} / \mathrm{l}, 0.22 \mathrm{mg} / \mathrm{l}$ and $0.23 \mathrm{mg} / \mathrm{l}$ in Keshaliya, Singhiya and Lohandra in the months of March, April and May, respectively. The amount of phosphate-phosphorus recorded $\mathrm{mg} / \mathrm{l}$ was comparatively less in all months in Lohandra. The reason behind this might be that the river receives fewer amounts of industrial effluents and domestic wastes.

\section{Dissolved oxygen}

Dissolved oxygen recorded in March,April and May for Keshaliya, Singhiya and Lohandra rivers were $7.73 \mathrm{mg} / 1,5.65 \mathrm{mg} / \mathrm{l}$ and $4.17 \mathrm{mg} / \mathrm{l} ; 10.6 \mathrm{mg} / \mathrm{l}, 7.03 \mathrm{mg} / \mathrm{l}$ and $4.17 \mathrm{mg} / \mathrm{l}$ and 8.05 $\mathrm{mg} / \mathrm{l}, 6.56 \mathrm{mg} / \mathrm{l}$ and $4.58 \mathrm{mg} / \mathrm{l}$, respectively (Table 1). The results showed that the values of DO in the month of May for all the rivers was acidic, which attributed to low volume of water in the rivers and raised in concentration due to dissolved organic and inorganic materials (Table 1).

\section{Biological Oxygen Demand (BOD)}


This is one of the important physico-chemical parameters of water of any source for determination of pollutant and oxygen. BOD values recorded for three months March, April and May in the waters of Keshaliya, Singhiya and Lohandra rivers came to be $9.27 \mathrm{mg} / \mathrm{l}$, $8.44 \mathrm{mg} / \mathrm{l}$ and $50.48 \mathrm{mg} / \mathrm{l}, 8.05 \mathrm{mg} / \mathrm{l}, 4.24 \mathrm{mg} / \mathrm{l}$, and $46.2 \mathrm{mg} / \mathrm{l}$, respectively (Table 1). The results indicated that BOD value of Keshaliya were comparatively more than those of Singhiya and Lohandra in all the months. The main reason might be, this river receives more industrial effluents from town and industries However, the BOD values of all the rivers inspected in three months fell in the same range that is moderately polluted (4 to 8 $\mathrm{mg} / \mathrm{l})$. But BOD values recorded in May in all rivers were high indicating polluted condition of rivers (Table 1).

\section{Chemical Oxygen Demand (COD)}

The amount of organics in rivers, lakes, reservoirs etc. can be easily quantify by a COD test. The most common application of COD is in quantifying the amount of oxidizable pollutants as well. The COD values of March, April and May in Keshaliya, Singhiya and Lohandra were $18.40 \mathrm{mg} / \mathrm{l}, 16.80 \mathrm{mg} / \mathrm{l}$, and $252 \mathrm{mg} / \mathrm{l} ; 9.20 \mathrm{mg} / \mathrm{l}, 8.40 \mathrm{mg} / \mathrm{l}$ and $100.80 \mathrm{mg} / \mathrm{l}$ and $9.20 \mathrm{mg} / \mathrm{l}, 8.40 \mathrm{mg} / \mathrm{l}$ and $92.40 \mathrm{mg} / \mathrm{l}$, respectively. In comparison, the values of COD in Lohandra appeared to have been more (Table 1) suggesting large amount of oxidizable pollutants in the surface water.

\section{Calcium}

The amounts of calcium recorded in the water samples from Keshaliya, Singhiya and Lohandra rivers were $64.28 \mathrm{mg} / \mathrm{l}, 72.29 \mathrm{mg} / \mathrm{l}$ and $61.17 \mathrm{mg} / \mathrm{l} ; 62.95 \mathrm{mg} / \mathrm{l}, 62.06 \mathrm{mg} / \mathrm{l}$ and $42.93 \mathrm{mg} / \mathrm{l}$ and $53.16 \mathrm{mg} / \mathrm{l}, 66.51 \mathrm{mg} / \mathrm{l}$ and $42.49 \mathrm{mg} / \mathrm{l}$ in the spring season. Its higher concentration was found in Keshaliya and Singhiya rivers. It might be due to greater alkalinity and hardness. As the values of $\mathrm{Ca}^{++}$were higher in all rivers, indicating rich in nutrients which showed their eutrophic nature.

\section{Magnesium}

It is an integral part of autotrophs being an important constituent of chlorophyll. The recorded values of magnesium in the Keshaliya, Singhiya and Lohandra in March, April and May were $13.12 \mathrm{mg} / \mathrm{l}, 8.75 \mathrm{mg} / \mathrm{l}, 9.90 \mathrm{mg} / \mathrm{l}, 15.07 \mathrm{mg} / \mathrm{l}, 13.85 \mathrm{mg} / \mathrm{l}$ and $21.4 \mathrm{mg} / \mathrm{l}$, and $12.15 \mathrm{mg} / \mathrm{l}, 4.13 \mathrm{mg} / \mathrm{l}$ and $11.9 \mathrm{mg} / \mathrm{l}$, respectively. It was found comparatively more in Singhiya river indicating hardness of water.

\section{Chloride}

It is considered as one of the pollution indicators when present in high concentration. The values of chloride recorded in the three rivers in spring season indicated that chloride values in all months were under the permissible limit except that of May in Keshaliya (36 $\mathrm{mg} / \mathrm{l}$ ) was beyond the permissible limit.

\section{Silica as $\mathrm{SiO}_{2}$}

The recorded values of silica in spring in Keshaliya, Singhiya and Lohandra were 252.38 $\mathrm{mg} / \mathrm{l}, 297.66 \mathrm{mg} / \mathrm{l}$ and $343.94 \mathrm{mg} / \mathrm{l}, 290.91 \mathrm{mg} / \mathrm{l}, 378.18 \mathrm{mg} / \mathrm{l}$ and $385.86 \mathrm{mg} / \mathrm{l}$, and 247.19 $\mathrm{mg} / \mathrm{l}, 314.29 \mathrm{mg} / \mathrm{l}$ and $330.64 \mathrm{mg} / \mathrm{l}$, respectively. The values of silica were found comparatively more in all three months in Lohandra which attributed to the weathering of 
the extremely abundant feldspar rocks. Silica is an essential nutrients for diatoms and also essential for the growth of planktonic chrysophyceans.

Table 1. Water parameters of Keshalyia, Lohandra and Singhiya rivers.

\begin{tabular}{llllllllll}
\hline \multirow{2}{*}{ Parameters } & \multicolumn{3}{c}{ Keshalyia River } & \multicolumn{3}{c}{ Lohandra River } & \multicolumn{3}{c}{ Singhiya River } \\
\cline { 2 - 9 } & March & April & May & March & April & May & March & April & May \\
\hline $\mathrm{P}^{\mathrm{H}}$ & 6.59 & 7.36 & 6.8 & 7.14 & 8.08 & 7.5 & 6.95 & 7.26 & 7.1 \\
$\mathrm{EC}$ & 523 & 455 & 537 & 387 & 336 & 338 & 452 & 435 & 433 \\
T (NTU) & 22.77 & 94 & 24.11 & 81 & 52 & 70 & 12.29 & 28.83 & 30.64 \\
Temp ( $\left.{ }^{\circ} \mathrm{C}\right)$ & 22.5 & 27.4 & 30 & 22.4 & 27 & 30.3 & 22.5 & 27.1 & 30.2 \\
TDS (mg/l) & 261.5 & 227.5 & 268.5 & 193.5 & 168 & 169 & 226 & 217.5 & 216.5 \\
TH (,,) & 199 & 199 & 179 & 170 & 167 & 145 & 204 & 197 & 185 \\
CH (,,) & 160.71 & 180.73 & 152.92 & 132.91 & 166.27 & 106.21 & 157.37 & 155.15 & 107.33 \\
TA (,,) & 204 & 212 & 216 & 180 & 172 & 176 & 212 & 202 & 226 \\
S (,,) & 252.38 & 297.66 & 393.94 & 247.19 & 314.29 & 330.64 & 290.91 & 378.18 & 385.86 \\
TN $(,)$, & 7 & 8.40 & 5.60 & 11.2 & 14 & 4.20 & 4.2 & 5.60 & 5.60 \\
TP (,,) & 0.21 & 0.45 & 0.33 & 0.18 & 0.22 & 0.23 & 0.07 & 0.22 & 0.23 \\
BOD (,,) & 9.27 & 8.44 & 126.52 & 4.79 & 4.24 & 46.20 & 4.60 & 4.24 & 50.48 \\
COD (,,) & 18.40 & 16.80 & 252 & 9.20 & 8.40 & 92.40 & 9.20 & 8.40 & 100.80 \\
DO (,,) & 7.73 & 5.65 & 4.17 & 8.05 & 6.56 & 4.58 & 10.65 & 7.01 & 4.17 \\
N (,,) & $<0.05$ & 0.09 & $<0.05$ & $<0.05$ & 0.18 & $<0.05$ & $<0.05$ & $<0.05$ & $<0.05$ \\
Cl (,,) & 24.99 & 11 & 36 & 6 & 4 & 12 & 11 & 13 & 13 \\
Ca (,,) & 64.28 & 8.75 & 9.96 & 53.16 & 4.13 & 11.9 & 62.95 & 13.85 & 21.4 \\
M (,,) & 13.12 & 72.29 & 61.17 & 12.15 & 66.51 & 42.49 & 15.07 & 62.06 & 42.93 \\
\hline
\end{tabular}

(EC- Electrical conductivity, T- Turbidity, Temp- Temperature, TDS- Total dissolved solids, TH- Total hardness as $\mathrm{CaCO}_{3}, \mathrm{CH}$ - Calcium hardness as $\mathrm{CaCO}_{3}$, TA- Total alkalinity as $\mathrm{CaCO}_{3}$, S- Silica as $\mathrm{SiO}_{2}$, TN- Total nitrogen, TP- Total phosphorus as PO4-P, N- Nitrate as $\mathrm{NO}_{3}-\mathrm{N}$, Cl- Chloride, Ca- Calcium, M- Magnesium).

\section{Conclusion}

From careful analysis of the results of water chemistry of the three rivers viz., Keshaliya, Singhita and Lohandra obtained it could be made clear that there appeared dominance of calcium over magnesium. BOD was higher in May in all rivers; it might be due to maximum deposition of organic matters which attributed to more nutrients load in all rivers. BOD was inversely proportional to DO. Higher values of BOD, TSD indicate that the poor quality of water for utility.

\section{Acknowledgement}

Authors would like to acknowledge sincerely with thanks to the service provider organization Nepal Environmental Service Centre (Nepal Batabarniya Sewa kendra) Biratnagar, Nepal for water analysis service provided.

\section{Reference}

APHA (American Public Health Assocation) 1998. Standard Methods for the Examination of Water and Wastewater $20^{\text {th }} \mathrm{Ed}$. American Public Health Association, Inc. New York. 